\title{
Water Quality, Climatic and Plant Traits as Predictors on Abundance of Insects in Paddy Field, Tanjung Karang, Selangor, Malaysia
}

\author{
Norazliza Rosly ${ }^{1}$, Mohd Rasdi Zaini ${ }^{2}$, Fauziah Ismail ${ }^{2}$, Fairuz Khalid ${ }^{2}$ and Ismail Rakibe ${ }^{2}$ \\ 1. Faculty of Plantation \& Agrotechnology, Universiti Teknologi MARA, Shah Alam 45400, Malaysia \\ 2. Faculty of Plantation \& Agrotechnology, Universiti Teknologi MARA, Melaka 77300, Malaysia
}

Received: July 23, 2014 / Published: August 20, 2014.

\begin{abstract}
The abundance of beneficial insects in the paddy field can be influenced by the abundance of insect pests, water parameters, climatic factors and plant traits. This study was conducted to determine effects of water parameters, climatic factors and plant traits on abundant insects. Findings of the studies showed that there were significant correlations between all beneficial insects in paddy field and water parameters tested, namely, water temperature, salinity, turbidity, $\mathrm{pH}$, dissolved oxygen, biological oxygen demand, chemical oxygen demand, ammonia and total suspended solids. Moreover, the selected water parameters of water temperature, dissolved oxygen, biological oxygen demand and chemical oxygen demand were good predictors for abundant beneficial insects in paddy field at Sungai Burong, specifically for insects of sub-orders Anisoptera and Zygoptera, and insects from families Gerridae and Coccinellidae. The plant height, insect pest, temperature, rainfall and humidity were found to be good predictors on the abundance of beneficial insects; nevertheless, the $R^{2}$ value of multiple regression models was relatively low due to significant relationship between water parameters and insects. Consideration factors of water parameters, climatic factors and plant traits were strongly correlated with those parameters and abundance of insects in the paddy field at Sungai Burong, Tanjung Karang, Selangor.
\end{abstract}

Key words: Water quality, paddy field, abundance, plant traits and insects.

\section{Introduction}

The physical and chemical properties of water play important roles in diversity, distribution and abundance of insects in the paddy field [1]. However, the abundance of insects and the quality of water parameters may possibly be influenced by plant height, temperature, rainfall and humidity. According to Norghauer and Newbery [2], both abundances of insects and plants performance were influenced by seasonal rainfall and canopy structure. Besides, there are several studies that have demonstrated the

Corresponding author: Mohd Rasdi Zaini, agriculture entomologist, Ph.D., senior lecturer, research field: agriculture entomology. E-mail: dddpim@pahang.uitm.edu.my; dddpim@yahoo.com. successful colonization of insects affected by the temperature, rainfall, air pressure, humidity and plant height [3-6]. Furthermore, study by Savopoulou-Soultani et al. [7], stated that the climatic factors such as temperature, rainfall and humidity could influence the abundance of insect populations. In addition, Kruess and Tscharntke [3] found that plant height was the major predictor for diverse population of the insects. Coulliette and Noble [8] found that heavy rainfall which caused storm-water run-off eventually affects the water quality. Therefore, the rainfall could probably wash out the fertilizer and pesticide residues toward the adjacent water bodies in the paddy field [9]. In addition, Xu et al. [10] reported that the water quality parameters, namely, nitrogen 
contents, phosphorus content, dissolved oxygen (DO), $\mathrm{pH}$ and chemical oxygen demand (COD) were responsible to the changes of temperature.

The presence of beneficial insects in the paddy field are very important for the ecological systems of paddy field as those insects help in the population management the pests and reduction of pesticides. Therefore, the presence of beneficial insects is one of the key resources to improve both productivity and sustainability in the paddy field [1]. The alteration in properties of water due to changes in plant height, temperature, rainfall and humidity may eventually influence the abundance of beneficial insects in the paddy field. Therefore, there was a requirement to investigate the effects of plant height, temperature, rainfall and humidity on quality of water in paddy fields.

\section{Materials and Methods}

\subsection{Study Area}

The study was carried out in paddy fields at Sungai Burong, one of the primary paddy fields in Malaysia which located at Tanjung Karang, $\left(3.4167^{\circ} \mathrm{N}\right.$, $101.1833^{\circ} \mathrm{E}$ ) in the state of Selangor. A total of 3221.84 hectares of paddy fields in Sungai Burong are irrigated by the nearby river named as Tengi River.

\subsection{Experimental Design}

A total of 12 stations were identified as sampling areas consisting of two localities namely paddy plots (yellow circle) and paddy drains (red circle) as shown in Fig. 1. The paddy inlet (turquoise circle) was the sources of water that used for irrigation of the paddy fields. Samplings were carried out for two cropping periods which started on October to December 2011 (for the first cropping) and February to May 2012 (for the second cropping). Samplings were done at all phenological phases of paddy growth. Each phase would attract different types of insect and have different physio-chemical contents in paddy water due to agronomic practices. There were three replications of collecting insect samples and three replications for each test of the water analysis at each sampling areas. As for collecting insect samples, one sweep of sweeping net (one meter) was considered as one replication.

\subsection{Sampling and Samples Analysis}

Insects were randomly collected by sweeping a hand net $(0.5 \mathrm{~mm})$. The hand net was dipped into the water and dragged about one meter in the paddy drain to collect the insect samples. Then, the trapped insects were transferred into labeled killing jars (chloroform).

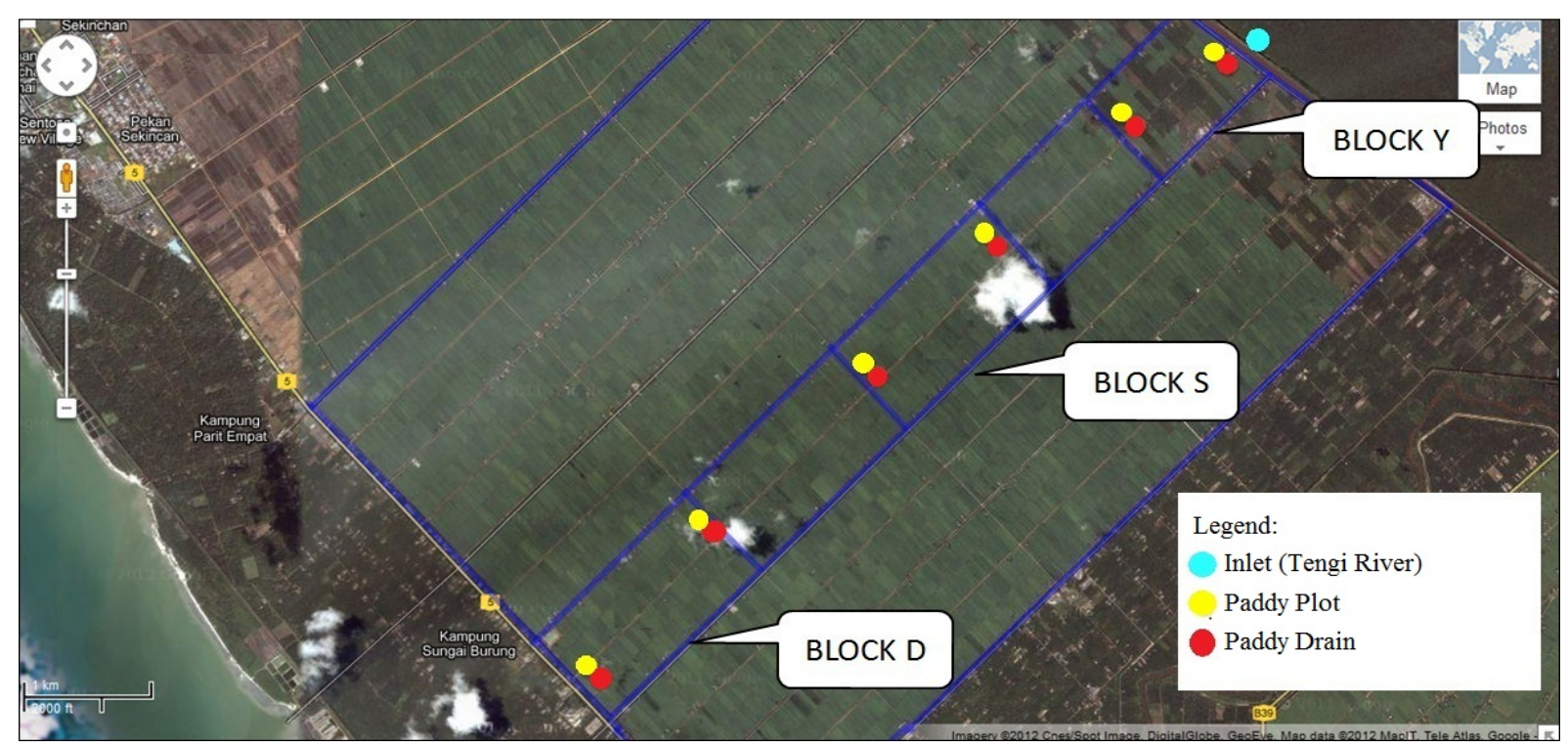

Fig. 1 Sampling areas. 
For wet preservation, killed insects were placed into another labeled killing jar (70\% ethyl alcohol). All samples were sorting, classifying and counting in the Entomology Laboratory, Faculty of Plantation and Agotechnology, Universiti Teknologi MARA. The water parameters, namely, water salinity, turbidity, $\mathrm{pH}$, temperature and DO were analyzed in-situ using YSI $550 A^{\circledR}$ Multi-Parameter probe, while the COD, biological oxygen demand (BOD), ammonia and total suspended solids (TSS) were analyzed in the laboratory following the methods that had been adopted from United State Environmental Protection Agency [11]. The climatic data was obtained from Malaysian Meteorology Department (MMD). A total of ten paddy plants were randomly chosen for measuring the height as representative of all paddy plants in each paddy plots. The plant height was measured manually using a tape measure.

\subsection{Data Analysis}

The diversity of insects collected from paddy field at Sungai Burong was calculated using Ecological Indices of Simpson's index $(d)$ and Shannon's index $\left(H^{\prime}\right)$. For the species richness of insects, both Margalef's index $\left(R_{1}\right)$ and Menhinick's index $\left(R_{2}\right)$ were used while the evenness values of insects estimate using Pielou's index $\left(\mathrm{J}^{\prime}\right)$. The multiple regressions of Statistical Package of Social Science (SPSS) version 19 was applied to predict effects of selected water parameters on the abundance of beneficial insects. The selection of water parameters variables in the multiple regression analysis was based on stepwise regression analysis. Besides, the Pearson's correlation of SPSS was also used to determine any relationships between plant height, temperature, rainfall, humidity and water parameters since the water parameters have significant effects on abundance of insects in paddy field [1]. Furthermore, the redundancy analysis (RDA) from CANOCO software package version 4.5 [12] with Monte Carlo test (499 permutations at $P<0.05$ ) was used to explain the complex interaction between species and environmental parameters [13, 14] that may have influences on the abundance of insects in the paddy field at Sungai Burong.

\section{Results}

\subsection{Effects of Water Parameters on the Abundance of Insects}

The $R^{2}$ values from multiple regression analysis for the first season of paddy planting shows that 63\% abundance of Anisoptera in the paddy field can be explained by the water parameters (Table 1). Moreover, the most selected water parameter that influenced and good predictor to the abundance of Anisoptera was BOD $(P<0.05)$. The $R^{2}$ value of the multiple regression models for Anisoptera at the second season was low as $47.7 \%$ (Table 2). Nevertheless, the water temperature and COD were good predictors to the abundance of the Zygoptera ( $P$ $<0.05$ ).

The multiple regression models used to predict effects of selected water parameters on the abundances of Gerridae (water striders) in the paddy field and it was only significant $(P<0.01)$ for the first season. The overall significance of the regression model between Gerridae and selected water parameters for the both seasons were 0.001 (Table 1) and 0.419 (Table 2), respectively. 54.2\% of selected water parameters (predictors) influenced the abundance of the Gerridae in the paddy field. Furthermore, amongst selected water parameters involved, only water temperature showed significant relationship $(P<0.05)$ with the abundance of Gerridae. Therefore, water temperature was a good predictor to the abundance of Gerridae at the first season of paddy planting but not in the second season. The overall significance of the regression model between the Coccinellidae (ladybird) and water parameters was 0.007 $(P<0.05)$ for the first season of paddy planting and $0.162(P>0.05)$ for the second season (Tables 1 and 2). 
Table 1 Multiple regression analysis between beneficial insects and water parameters on the first season of paddy planting.

\begin{tabular}{|c|c|c|c|c|c|c|c|c|c|}
\hline \multirow[b]{2}{*}{$\begin{array}{l}\text { Dependent } \\
\text { variables }\end{array}$} & & \multicolumn{8}{|c|}{ Predictors } \\
\hline & & Constant & $\begin{array}{l}\text { Water } \\
\text { temperature }\end{array}$ & Salinity & $\begin{array}{l}\text { Dissolved } \\
\text { oxygen }\end{array}$ & $\mathrm{pH}$ & $\begin{array}{l}\text { Biological } \\
\text { oxygen } \\
\text { demand } \\
\end{array}$ & $\begin{array}{l}\text { Chemical } \\
\text { oxygen } \\
\text { demand }\end{array}$ & Ammonia \\
\hline \multirow{4}{*}{ Anisoptera } & Coefficient & & 0.225 & -0.067 & 0.263 & 0.427 & 0.284 & 0.104 & 0.099 \\
\hline & $t$ & -2.741 & 1.745 & -0.495 & 0.723 & 1.191 & 2.346 & 0.772 & 0.770 \\
\hline & $P$ & $0.000^{(\mathrm{s})}$ & 0.920 & 0.624 & 0.476 & 0.244 & $0.026^{(\mathrm{s})}$ & 0.447 & 0.448 \\
\hline & $R^{2}$ & 0.630 & & & & & & & \\
\hline \multirow{4}{*}{ Zygoptera } & Coefficient & & 0.699 & -0.115 & 0.256 & -0.349 & 0.026 & -0.051 & 0.023 \\
\hline & $t$ & -2.467 & 4.387 & -0.719 & 0.597 & -0.825 & 0.179 & -0.321 & 0.150 \\
\hline & $P$ & $0.005^{(\mathrm{s})}$ & $0.000^{(\mathrm{s})}$ & 0.478 & 0.555 & 0.416 & 0.859 & 0.751 & 0.882 \\
\hline & $R^{2}$ & 0.485 & & & & & & & \\
\hline \multirow{4}{*}{ Gerridae } & Coefficient & & -0.312 & 0.230 & 0.327 & 0.228 & -0.032 & 0.245 & -0.171 \\
\hline & $t$ & 1.384 & -2.169 & 1.527 & 0.810 & 0.571 & -0.239 & 1.636 & 1.199 \\
\hline & $P$ & $0.001^{(\mathrm{s})}$ & $0.039^{(\mathrm{s})}$ & 0.138 & 0.425 & 0.572 & 0.813 & 0.113 & 0.241 \\
\hline & $R^{2}$ & 0.542 & & & & & & & \\
\hline \multirow{4}{*}{ Coccinellidae } & Coefficient & & 0.511 & -0.272 & 0.280 & -0.343 & 0.170 & -0.198 & 0.141 \\
\hline & $t$ & -2.519 & 3.315 & -1.682 & 0.646 & -0.801 & 1.171 & -1.232 & 0.924 \\
\hline & $P$ & $0.007^{(\mathrm{s})}$ & $0.003^{(\mathrm{s})}$ & 0.104 & 0.523 & 0.430 & 0.251 & 0.228 & 0.363 \\
\hline & $R^{2}$ & 0.472 & & & & & & & \\
\hline \multirow{4}{*}{ Staphylinidae } & Coefficient & & 0.307 & -0.274 & 0.960 & -0.874 & 0.422 & -0.030 & 0.020 \\
\hline & $t$ & -2.634 & 1.808 & -1.542 & 2.013 & -1.856 & 2.653 & -0.167 & 0.120 \\
\hline & $P$ & 0.058 & 0.081 & 0.134 & $0.054^{(\mathrm{s})}$ & 0.074 & $0.013^{(\mathrm{s})}$ & 0.868 & 0.906 \\
\hline & $R^{2}$ & 0.362 & & & & & & & \\
\hline
\end{tabular}

(s) is significant at $P<0.05$.

Table 2 Multiple regression analysis between beneficial insects and water parameters on the second season of paddy planting.

\begin{tabular}{|c|c|c|c|c|c|c|c|c|c|}
\hline \multirow[b]{2}{*}{$\begin{array}{l}\text { Dependent } \\
\text { variables }\end{array}$} & & \multicolumn{8}{|c|}{ Predictors } \\
\hline & & Constant & $\begin{array}{l}\text { Water } \\
\text { temperature }\end{array}$ & Salinity & $\begin{array}{l}\text { Dissolved } \\
\text { oxygen }\end{array}$ & $\mathrm{pH}$ & $\begin{array}{l}\text { Biological } \\
\text { oxygen } \\
\text { demand }\end{array}$ & $\begin{array}{l}\text { Chemical } \\
\text { oxygen } \\
\text { demand } \\
\end{array}$ & Ammonia \\
\hline \multirow{4}{*}{ Anisoptera } & Coefficient & & 0.870 & 0.081 & -0.262 & -0.134 & 0.233 & -0.852 & -0.171 \\
\hline & $t$ & 0.088 & 2.437 & 0.509 & -1.491 & -0.563 & 0.530 & -3.716 & -0.878 \\
\hline & $P$ & 0.060 & $0.021^{(\mathrm{s})}$ & 0.615 & 0.147 & 0.578 & 0.600 & $0.001^{(\mathrm{s})}$ & 0.387 \\
\hline & $R^{2}$ & 0.477 & & & & & & & \\
\hline \multirow{4}{*}{ Zygoptera } & Coefficient & & -0.281 & 0.212 & 0.125 & -0.121 & 0.399 & 0.163 & 0.138 \\
\hline & $t$ & 0.089 & -0.626 & -1.052 & 0.567 & -0.407 & 0.702 & 0.565 & 0.563 \\
\hline & $P$ & 0.571 & 0.536 & 0.302 & 0.575 & 0.687 & 0.477 & 0.576 & 0.578 \\
\hline & $R^{2}$ & 0.172 & & & & & & & \\
\hline \multirow{4}{*}{ Gerridae } & Coefficient & & 0.118 & 0.335 & -0.068 & -0.079 & -0.265 & 0.217 & 0.217 \\
\hline & $t$ & 0.232 & 0.270 & 1.705 & -0.316 & 0.270 & -0.489 & 0.768 & 1.130 \\
\hline & $P$ & 0.419 & 0.789 & 0.990 & 0.754 & 0.789 & 0.629 & 0.449 & 0.268 \\
\hline & $R^{2}$ & 0.208 & & & & & & & \\
\hline \multirow{4}{*}{ Coccinellidae } & Coefficient & & -0.295 & -0.234 & -0.028 & -0.532 & 1.047 & -0.096 & 0.124 \\
\hline & $t$ & 0.116 & -0.711 & -1.260 & -0.137 & -1.932 & 2.044 & -0.360 & -0.545 \\
\hline & $P$ & 0.162 & 0.483 & 0.218 & 0.892 & 0.064 & $0.050^{(\mathrm{s})}$ & 0.722 & 0.590 \\
\hline & $R^{2}$ & 0.292 & & & & & & & \\
\hline \multirow{4}{*}{ Staphylinidae } & Coefficient & & -0.730 & -0.347 & -0.248 & -0.163 & 1.157 & 0.197 & -0.401 \\
\hline & $t$ & 0.038 & -1.731 & -1.837 & -1.197 & -0.581 & 2.224 & 0.729 & 1.741 \\
\hline & $P$ & 0.214 & 0.094 & 0.770 & 0.241 & 0.566 & $0.034^{(\mathrm{s})}$ & 0.472 & 0.093 \\
\hline & $R^{2}$ & 0.270 & & & & & & & \\
\hline
\end{tabular}

\footnotetext{
(s) is significant at $P<0.05$.
} 
The multiple regression models for the first season were accepted to predict the effects of the water parameters on the abundance of Coccinellidae in the paddy field. However, the $R^{2}$ value for the multiple regression models was low with 0.472 and 0.292 for the first and second seasons, respectively. The water temperature and BOD were good predictors for the abundance of Coccinellidae at the first and second seasons of paddy planting, respectively. The multiple regression model for Staphylinidae for two seasons of paddy planting (Tables 1 and 2) were not validated to predict the effects of water parameters on abundance of Staphylinidae in the paddy field at Sungai Burong. Overall, the significance of the regression model for the first and second seasons of paddy planting were 0.058 and $0.214(P>0.05)$, respectively.

\subsection{Relationship between Climatic Factors, Plant} Traits and Insect Pests with Water Parameter

Result in Table 3 shows that there was a significant relationship $(P<0.05)$ between water temperature and COD with plant height during the first season of paddy planting. The COD had negative relationship with plant height, thus value of chemical oxygen was decreased as increasing the plant height. The other water parameters did not show any significant relationship with plant height as the $P$-value was greater than 0.05 during the first season. However, at the second season of paddy planting, DO was significantly ( $R=0.430$ and $P<0.01)$ associated with plant height (Table 4). In addition, BOD, COD, ammonia and TSS were strongly related $(P<0.05)$ to temperature and humidity at the second season of paddy planting.

\subsection{Relationship between Water Parameter and Plant} Height on Abundance of Insects

According to the previous findings, the plant height, temperature and rainfall showed significantly associated with quality of water and influenced abundance of beneficial insects in the paddy field. These findings indicated that the water parameters, temperature, rainfall and plant height had significant relationship with beneficial insects in the paddy fields. The RDA was able to simplify complex interaction between environmental factors and abundance of insects in the paddy field.

For first season, most of environmental factors namely $\mathrm{pH}$, BOD, COD, and plant height were assemblage on the first axis (Fig. 2) of the RDA ordination biplot diagram. The other two environmental factors, water temperature and DO were assemblage in the second axis (Fig. 2) of RDA ordination plot. The eigenvalues for the first axis (Fig. 2) is 0.777 which was more than 0.800 (Table 5). This indicated that relationship between $\mathrm{pH}, \mathrm{COD}$, ammonia and plant height with abundance of insects were very strong. However, only BOD showed negative relationship with abundance of insect, while other parameters include $\mathrm{pH}$, COD, ammonia and plant height showed positive correlation with abundance of insects. As for the second season, six

Table 3 Pearson's correlation analysis of relationship of the water parameters with plant height in the first season of paddy planting.

\begin{tabular}{ll}
\hline Water prameters & Plant height \\
\hline Temperature & $R=0.741^{(\mathrm{s})}$ \\
& $P=0.000$ \\
Salinity & $R=-0.290$ \\
& $P=0.087$ \\
Turbidity & $R=-0.269$ \\
& $P=0.112$ \\
Dissolved oxygen & $R=-0.050$ \\
pH & $P=0.772$ \\
Biological oxygen demand & $R=-0.081$ \\
Chemical oxygen demand & $P=0.641$ \\
Ammonia & $R=-0.061$ \\
& $P=0.725$ \\
Total suspended solid & $R=-0.593^{(\mathrm{s})}$ \\
\end{tabular}

(s) is significant at $P<0.05$. 
Table 4 Pearson's correlation analysis of relationship of the water parameters with plant height in the second season of paddy planting.

\begin{tabular}{|c|c|c|c|c|}
\hline Water parameters & Plant height & Temperature & Humidity & Rainfall \\
\hline \multirow{2}{*}{ Temperature } & $R=0.170$ & $R=0.159$ & $R=-0.180$ & $R=0.055$ \\
\hline & $P=0.322$ & $P=0.356$ & $P=0.293$ & $P=0.752$ \\
\hline \multirow{2}{*}{ Salinity } & $R=-0.158$ & $R=0.254$ & $R=-0.261$ & $R=-0.084$ \\
\hline & $P=0.357$ & $P=0.134$ & $P=0.124$ & $P=0.627$ \\
\hline \multirow{2}{*}{ Turbidity } & $R=-0.065$ & $R=0.208$ & $R=-0.230$ & $R=0.030$ \\
\hline & $P=0.706$ & $P=0.223$ & $P=0.178$ & $P=0.863$ \\
\hline \multirow{2}{*}{ Dissolved oxygen } & $R=0.430^{(\mathrm{s})}$ & $R=0.106$ & $R=-0.134$ & $R=0.120$ \\
\hline & $P=0.009$ & $P=0.539$ & $P=0.436$ & $P=0.484$ \\
\hline \multirow{2}{*}{$\mathrm{pH}$} & $R=-0.062$ & $R=0.084$ & $R=-0.099$ & $R=0.049$ \\
\hline & $P=0.721$ & $P=0.626$ & $P=0.567$ & $P=0.776$ \\
\hline \multirow{2}{*}{ Biological oxygen demand } & $R=0.271$ & $R=0.403^{(\mathrm{s})}$ & $R=-0.455^{(\mathrm{s})}$ & $R=0.121$ \\
\hline & $P=0.109$ & $P=0.015$ & $P=0.005$ & $P=0.483$ \\
\hline \multirow{2}{*}{ Chemical oxygen demand } & $R=0.209$ & $R=0.384^{(\mathrm{s})}$ & $R=-0.432^{(\mathrm{s})}$ & $R=-0.111$ \\
\hline & $P=0.221$ & $P=0.021$ & $P=0.008$ & $P=0.518$ \\
\hline \multirow{2}{*}{ Ammonia } & $R=0.184$ & $R=0.587^{(\mathrm{s})}$ & $R=-0.650^{(\mathrm{s})}$ & $R=0.100$ \\
\hline & $P=0.283$ & $P=0.000$ & $P=0.000$ & $P=0.560$ \\
\hline \multirow{2}{*}{ Total Suspended Solid } & $R=-0.046$ & $R=-0.451^{(\mathrm{s})}$ & $R=0.503^{(\mathrm{s})}$ & $R=-0.096$ \\
\hline & $P=0.790$ & $P=0.006$ & $P=0.002$ & $P=0.577$ \\
\hline
\end{tabular}

(s) is significant at $P<0.05$.

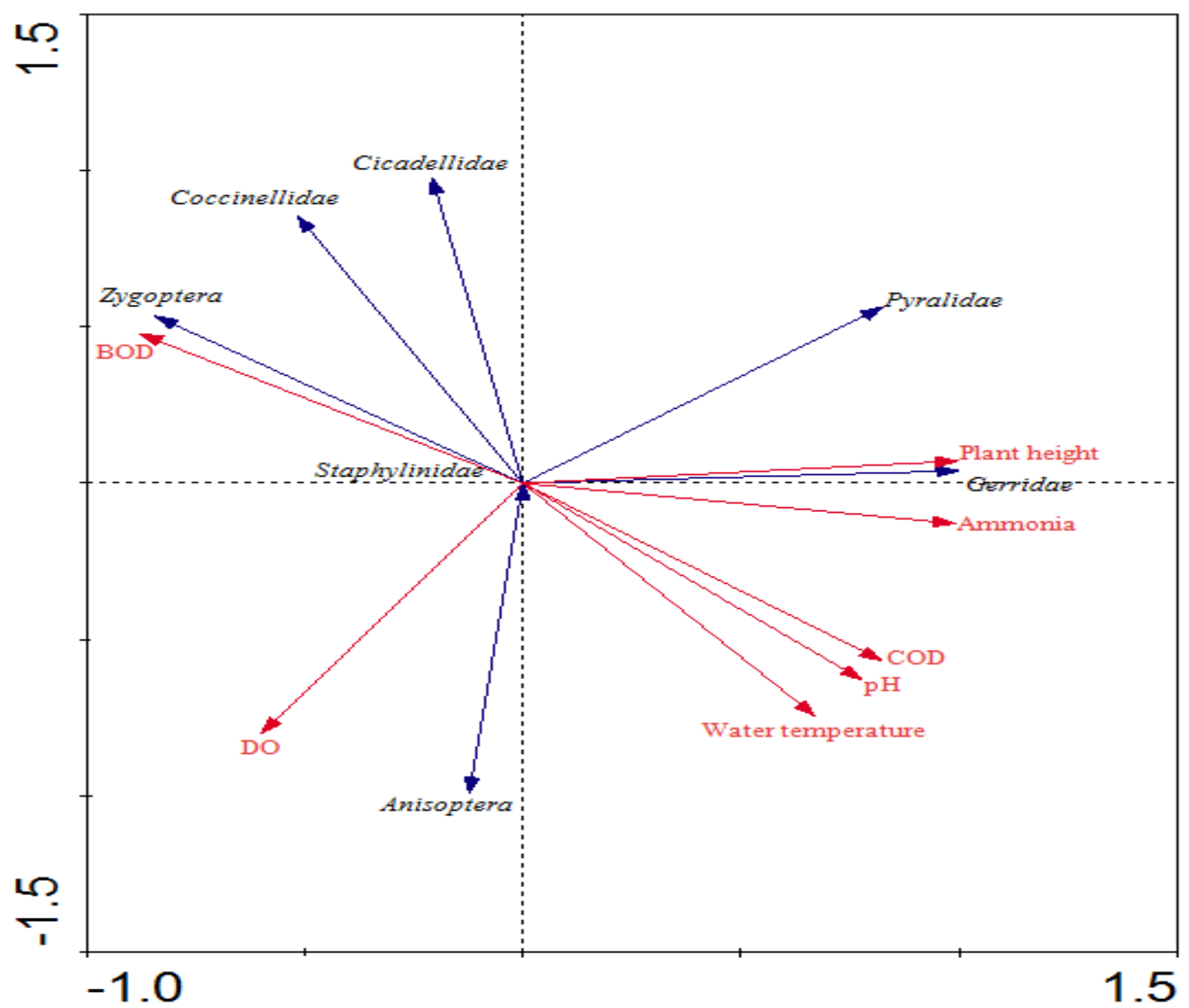

Fig. 2 Redundancy analysis ordination diagram with insects and water temperature, biological oxygen demand, chemical oxygen demand, ammonia, dissolved oxygen, $\mathrm{pH}$ and plant height axis lengths in standard deviation units for the first season. 
Table 5 Correlation, eigenvalues and variance demonstrate for two axis of redundancy analysis for insects and water temperature, biological oxygen demand, chemical oxygen demand, ammonia, dissolved oxygen, pH and plant height of first season.

\begin{tabular}{lll}
\hline Variables & Axis 1 & Axis 2 \\
\hline Water temperature & 0.669 & -0.744 \\
Biological oxygen demand & -0.878 & 0.480 \\
Chemical oxygen demand & 0.823 & -0.568 \\
Ammonia & 0.992 & -0.128 \\
Dissolved oxygen & -0.599 & -0.801 \\
pH & 0.777 & -0.630 \\
Plant height & 0.997 & 0.073 \\
Eigenvalues & 0.969 & 0.031 \\
Species-environment correlation & 1.000 & 1.000 \\
Cumulative percentage variance & & \\
of species data & 96.900 & 100.000 \\
of species-environment relation & 96.900 & 100.000 \\
\hline
\end{tabular}

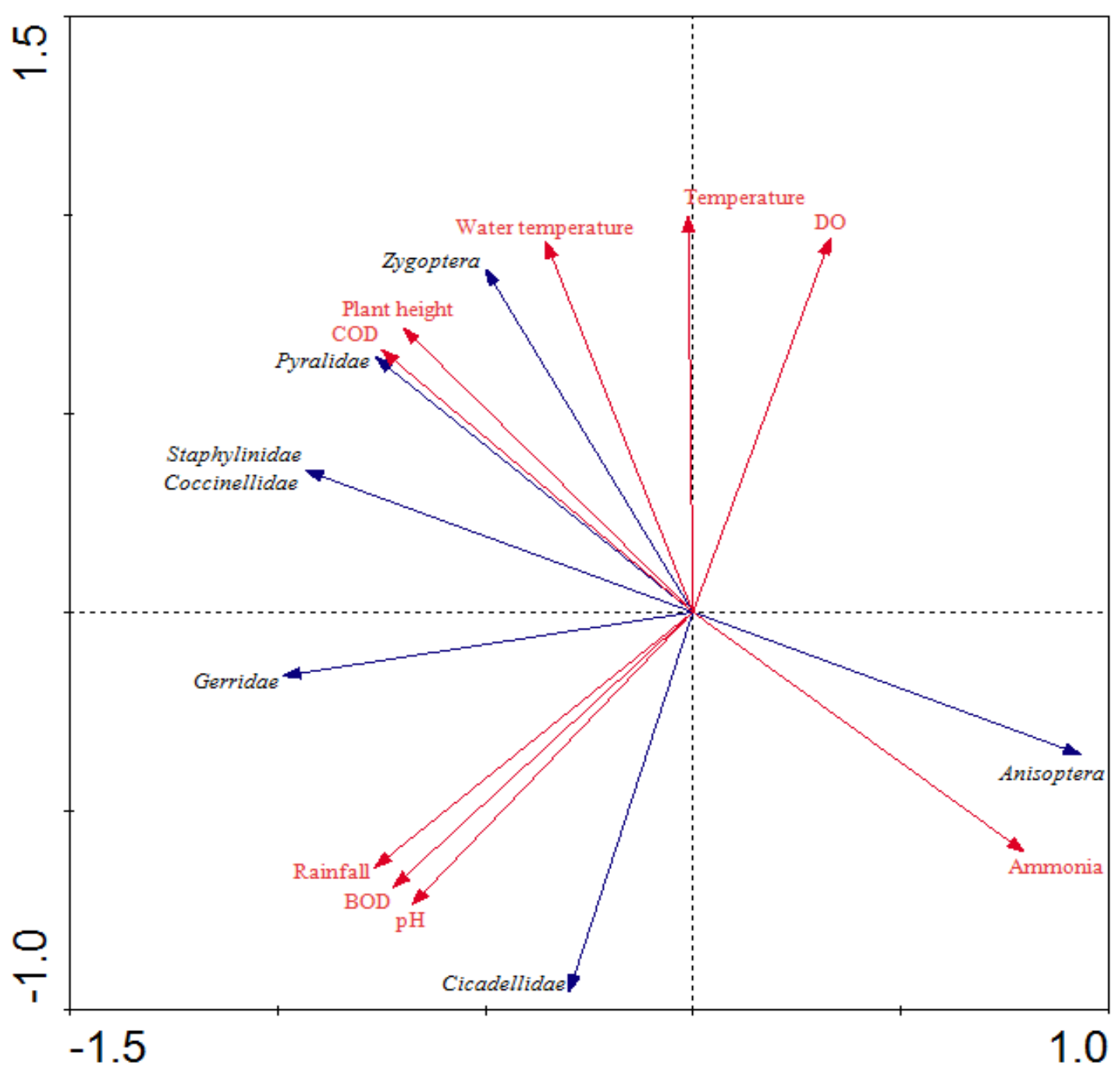

Fig. 3 Redundancy analysis ordination diagram with insects and water temperature, biological oxygen demand, chemical oxygen demand, ammonia, dissolved oxygen, $\mathrm{pH}$ and plant height axis lengths in standard deviation units for the second season. 
Table 6 Correlation, eigenvalues and variance demonstrate for two axis of redundancy analysis for insects and water temperature, biological oxygen demand, chemical oxygen demand, ammonia, dissolved oxygen, pH and plant height of second season.

\begin{tabular}{lll}
\hline Variables & Axis 1 & Axis 2 \\
\hline Water temperature & -0.354 & 0.935 \\
Biological oxygen demand & -0.721 & -0.693 \\
Chemical oxygen demand & -0.750 & 0.661 \\
Ammonia & 0.797 & -0.604 \\
Dissolved oxygen & 0.330 & 0.944 \\
pH & -0.677 & -0.736 \\
Plant height & -0.698 & 0.716 \\
Temperature & -0.012 & 1.000 \\
Rainfall & -0.766 & -0.643 \\
Humidity & 0.181 & -0.983 \\
Eigenvalues & 0.788 & 0.212 \\
Species-environment correlation & 1.000 & 1.000 \\
Cumulative percentage variance & & \\
of species data & 78.800 & 100.000 \\
of species-environment relation & 78.800 & 100.000 \\
\hline
\end{tabular}

out of the ten environmental factors namely water temperature, $\mathrm{pH}$, DO, plant height, temperature and humidity found to be in the second axis (Fig. 3) of RDA ordination biplot diagram. The remaining four variables which are BOD, COD, ammonia and rainfall, were assemblage in the first axis (Fig. 3) of the RDA ordination biplot diagram. The eigenvalues of environmental factors in the first and second axis found to be more than 0.7000 . The eigenvalues at the first axis for BOD, COD, ammonia and rainfall were $-0.721,-0.750,0.798$ and -0.766 , respectively. The eigenvalues of water temperature, $\mathrm{pH}$, DO, plant height, temperature and humidity at the second axis of RDA ordination biplot diagram (Table 6) were 0.935, $-0.736,0.944,0.716,1.000$ and -0.983 , respectively.

\section{Discussion}

Results of multiple regression models showed that this model could predict the effects of selected water parameters on abundance of beneficial insects in the paddy field. However, most of selected water parameters such as temperature, salinity, $\mathrm{DO}, \mathrm{pH}$, BOD, COD and ammonia were not be able to explain the abundance of the beneficial insects in the paddy field due to low $R^{2}$ values. Therefore, there were some factors aside from the selected water parameters namely temperature, salinity, DO, $\mathrm{pH}, \mathrm{BOD}, \mathrm{COD}$ and ammonia that probably could influence the abundance of insects in the paddy field. Those possible variables are such as climatic factors and plant traits.

During the first season of paddy planting, water temperature was good predictor for Zygoptera, Gerridae and Coccinellidae (Table 1). According to the Corbet [15] water temperature was known as one of the main factors in the habitat preferences for oviposition of Zygoptera. Besides, Suh and Samways [16] noted that Odonata (Anisoptera and Zygoptera) was significantly influenced by water temperature and ambient temperature. There were no specific research for relationship between water temperature and water striders (Gerridae). However, study by Nummelin et al. [17] had detected higher concentration of iron and manganese contents in Gerridae (water strider) in areas near the factory compared to the control area. The presence of heavy metal (iron and manganese) in water probably caused increase of water temperature. Therefore, there was a possibility that water striders could tolerate with high water temperature. The Coccinellidae and Staphylinidae were recognized as 
terrestrial insects in the paddy field. However, according to the multiple regression's results in Table 1, Coccinellidae was found had significant correlation with water temperature during the first season of paddy planting, while the Staphylinidae shows significant correlation with BOD at the both seasons. Findings of this study suggest that there were possibility of indirect relationship between water plant uptake with the abundance of Coccinellidae and Staphylinidae in the paddy field. Water temperature can be influenced by environmental factors such as rainfall, temperature and vegetative shading around the sampling area [18]. Besides that, water temperature could also be influenced by concentration of pesticides and fertilizers application [19].

Based on the Pearson's correlation results (Tables 3 and 4), significant correlation was observed between plant height with water temperature. Besides, there is also significant correlation between plant height with COD. However, the results showed that only water temperature had positive correlation with plant height while, the COD had negative correlation with the plant height. There were very few studies regarding the relationship between plant height and water temperature. However, Sugiyama and Hama [20] found that high water temperature leads to high absorption of phosphorus in sediment. Phosphorus is one of nutrient that essential for all crops including paddy plants. Chen et al. [21] found that low absorption of phosphorus will slow down the rate of leaf emergence thus, slow down the growth of the plant. Therefore, as the water temperature decreased, the growth of plant also will be decreased (Table 3).

A significant correlation detected between temperature with COD, BOD, ammonia and TSS as shown in Table 4 . Temperature was detected to have positive correlation with COD, BOD and ammonia, nevertheless negative relationship with TSS. As the temperature increase, the heat of water bodies will increase. This would lead to higher respiration under the water bodies. As a result, the DO available in water bodies was decreasing due to high amount of oxygen used by the aquatic organism, thus amount of BOD would increased. Lack of DO in water bodies could cause aquatic organism stress, suffocate and eventually died. The degradation of died organism in water bodies lead to increase of nitrogen and ammonia contents in the water bodies. It is proper to mention that the amount of COD would increase due to high amount of organic compound in water [22, 23]. Therefore, it is understood that as the temperature increase, water quality parameters such as BOD, COD and ammonia will also increase. Besides that, humidity was detected to have negative correlation with COD, BOD and ammonia. In addition, the humidity had positive significant correlation with TSS. This indicated that as the humidity increase, amount of COD, BOD and ammonia will decrease. However, the amount of TSS in paddy water will decrease. A few studies were carried out on effects of humidity to water parameters. Most of studies [24-28] were agreed that temperature was oppositely related with humidity which as the temperature increases, the humidity will decrease. The humidity was defined as an amount of water that the air could hold at the specific temperature. Therefore, amount of humidity might be depleted as the temperature increased. This result was contradictory to humidity (Table 4) probably due to a negative correlation of humidity with BOD, COD and ammonia. It is concluded, therefore, that humidity had inversely correlation with temperature, but humidity and temperature had significant correlation with BOD, COD, ammonia and TSS in water bodies.

Considering all variables together in redundancy analysis (Figs. 2 and 3), ammonia appeared as the most variables that influenced the abundances of the most insects for two seasons of paddy planting. However, inverse relationship was observed between ammonia and abundance of most insects in paddy field. Consequently, the abundance of most insects, namely, Zygoptera, Coccinellidae and Cicadellidae 
were decreasing as the ammonia increasing. The ammonia's content in paddy field probably due to continuous application of fertilizers in the paddy field. Moreover, the results indicated that insects from order of Anisoptera were negatively correlated with plant height at two seasons of paddy planting. Study by Fox and Cham [29] found that areas that have less than $50 \%$ of vegetations indicated as a good habitat for the colonization of Anisoptera, prior breeding and oviposition. Thus, as the height of paddy plant increased, the oviposition of Anisoptera would decrease resulting in low abundance of Anisoptera in the paddy field.

\section{Conclusions}

After considering all factors such as water parameters, plant height, insect pests, temperature, humidity and rainfall that could influence the abundance of beneficial insects in paddy field at Sungai Burong, it was found that ammonia content in the water bodies were the most influenced factor to the abundance of insects. However, ammonia content affected the abundance of beneficial insects in the paddy field. Therefore, the findings suggest that farmers should apply the amount of fertilizers at optimum recommendated dosage as shown in the labeling package. It was highly recommended that the water quality either in paddy inlet or the paddy fields need to be maintained and monitored since the insects have an alternate habitats. The parameters namely insects pests (Pyralidae (moths), Cicadellidae (green leafhoppers) and Chironomidae (midges)), water temperature, BOD, COD, ammonia, $\mathrm{DO}, \mathrm{pH}$, plant height, temperature, rainfall and humidity have high influence on the abundance of beneficial insects in the paddy fields specifically at Sungai Burong, Tanjung Karang, Selangor.

\section{Acknowledgments}

We acknowledge the Research Management Institute (RMI), Universiti Teknologi MARA Shah
Alam for financial support (excellent funds: 600-RMI/ST/DANA 5/3/Dst (24/2011)). We also acknowledge Faculty of Plantation and Agrotechnology, UiTM Shah Alam for providing laboratory facilities.

\section{References}

[1] Norazliza, R., Fauziah, I., Mohd Rasdi, Z., Fairuz, K., and Ismail, R. 2014. "Comparison and Relationship between Water Parameters an Abundance of Insects in Field and Irrigation System of Paddy Area of Sungai Burong, Tanjung Karang, Selangor, Malaysia.” Journal of Agriculture, Forestry and Fisheries 3 (4): 249-56.

[2] Noughauer, J. M., and Newbert, D. M. 2013. "Herbivores Equalize the Seedling Height Growth of Three Dominant Tree Species in an African Tropical Rain Forest.” Journal of Forest Ecology and Management 310: 555-66.

[3] Kruess, A., and Tscharntke, T. 2002. "Contrasting Responses of Plant and Insect Diversity to Variation in Grazing Intensity.” Biological Conservation 106: 203-302.

[4] Anu, A., Sabu, T. K., and Vineesh, P. J. 2009. "Seasonality of Litter Insects and Relationship with Rainfall in a Wet Evergreen Forest in Westrern Ghats.” Journal of Insect Science 9: 10.

[5] Regniere, J., Powell, J., Bentz, B., and Nealis, V. 2012. "Effects of Temperature on Development, Survival and Reproduction of Insects: Experimental Design, Data Analysis and Modeling.” Journal of Insects Physiology 58: 634-47.

[6] George, K. A., Archer, M. S., and Toop, T. 2013. "Abiotic Environmental Factors Influencing Blowfly Colonization Pattern in the Paddy Field.” Forensic Science International 229: 100-7.

[7] Savopoulou-Soultani, M., Papadopoulos, N. T., Milonas, P., and Moyal, P. 2012. "Abiotic Factors and Insect Abundance.” Psyche 2012: 1-2.

[8] Coulliette, A. D., and Noble, R. T. 2008. "Impacts of Rainfall on the Water Quality of the Newport River Estuary (Eastern North Carolina, USA).” Journal of Water and Health 6 (4): 473-82.

[9] Linde, C. D. 1994. Physio-chemical Properties and Environmental Fate of Pesticides. California: Department of Pesticides Regulation, 56.

[10] Xu, L., Li, H., Liang, X., Yau, Y., Zhou, L., and Cui, X. 2012. "Water Quality Parameters Response to Temperature Change in Small Shallow Lakes.” Physics and Chemistry of the Earth 47 (8): 128-34.

[11] United State Environmental Protection Agency (USEPA). 2004. Wadeable Streams Assessment: Water Chemistry 
Laboratory Manual. Washington, DC: USEPA, 47.

[12] ter Braak, C. J. F., and Smilauer, P. 2002. Canoco for Windows Version 4.5. Wageningen, the Netherlands: Biometris Plant Research International, 500.

[13] ter Braak, C. J. F. 1989. "CANOCO-An Extension of DECORA-NA to Analyze Species-Environment Relationships." Hydrobiologia 181: 169-70.

[14] Canobbio, S., Mezanotte, V., Sanfilippo, U., and Benvenuto, F. 2009. "Effect of Multiple Stressor on Water Quality and Macroinvertebrate Assemblages in an Effluent-Dominated Stream.” Water, Air and Soil Pollution 198: 359-71.

[15] Corbet, P. S. 1962. A Biology of Dragonflies. London: H. F. and G. Witherby Ltd., 136.

[16] Suh, A. N., and Samways, M. J. 2001. "Development of Dragonfly Awareness Trail in an African Botanical Garden.” Journal of Biological Conservation 100: 345-53.

[17] Nummelin, M., Lodenius, M., Tulisalo, E., Hirvonen, H., and Alanko, T. 2007. "Predatory Insects as Bioindicators of Heavy Metal Pollution.” Journal of Environmental Pollution 14: 339-47.

[18] Environmental Protection Agencies (EPA). 2012. "Water Quality Conditions.” Unite States Environmental Protection Agencies. Accessed January, 2014. http://water.epa.gov/type/rsl/monitoring/vms50.cfm.

[19] Gossum, H. V., Bots, J., Snijkers, T., Meyer, J., Wassenbergh, S. W., Coen, W. D., and Bruyn, L. D. 2009. "Behaviour of Damselfly Larvae (Enallagma cyathigerum) (Insecta, Odonata) after Long-Term Exposure to PFOS.” Journal of Environmental Pollution 157: 1332-6.

[20] Sugiyama, S., and Hama, T. 2013. "Effects of Water Temperature on Phosphate Adsorption onto Sediments in an Agricultural Drainage Canal in a Paddy-Field District.” Journal of Ecological Engineering 61: 94-9.

[21] Chen, F. J., Liu, X. S., and Mi, G. H. 2012. "Varietal
Differences in Plant Growth, Phosphorus Uptake and Yield Formation in Two Maize Inbred Lined Grown under Field Condition.” Journal of Integrative Agriculture 11 (10): 1738-43.

[22] Eugene, R. W. 2000. Application of Environmental Chemistry: A Practical Guide for Environmental Professional. United States of Amerika: Lewis Publisher, 276.

[23] Batti, A. M., Suttinon, P., and Nasu, S. 2011. "The Potential Impacts of Temperature Change on Water Quality Parameter in Yoshio River, Japan.” Society for Social Management Systems. Accessed January, 2014. http://management.kochi-tech.ac.jp/ssms_papers/sms11-9 195_90277702b72599fe8c426537f7690ba2.pdf.

[24] Rowly, W. A., and Graham, C. L. 1968. "The Effect of Temperature and Relative Humidity on the Flight Performance of Female Aedes aegypti.” Journal of Insect Physiology 14: 1251-7.

[25] Elovitz, K. M. 1999. "Understanding What Humidity Does and Why.” Ashrae Journal 75-81.

[26] Lawrence, M. G. 2005. "The Relationship between Relative Humidity and the Dewpoint Temperature in Moist Air.” American Meteorological Society 86: 225-33.

[27] Shelton, D. P. 2008. Air Properties: Temperature and Relative Humidity. Nebraska: University of Nebraska-Lincoln Extension Publication.

[28] Harp, D. A., and Suttle, C. 2009. "Relationship between Air Temperature, Relative Humidity, Wind Speed and Evapotranspiration in Green Roof Plants in the Southern United States.” Presented at the Seventh International Conference on Urban Climate [Poster]. Yokohama, Japan.

[29] Fox, A. D., and Cham, S. A. 1994. "Status, Habitat Use and Conservation of the Scarce Blue-Tailed Damselfly Ischnura pumilio (Charpentier) (Odonata: Coenagrionidae) in Britain and Ireland.” Journal of Biological Conservation 68: 115-22. 